\title{
Wind-driven settlement patterns in the acorn barnacle Semibalanus balanoides
}

\author{
Mark D. Bertness*, Steven D. Gaines**, Richard A. Wahle*** \\ Department of Ecology and Evolutionary Biology, Brown University, Providence, Rhode Island 02912, USA
}

\begin{abstract}
We quantified daily larval settlement of the acorn barnacle Semibalanus balanoides in a small embayment within Narragansett Bay, Rhode Island, USA, to examine the hypothesis that local wind patterns influence shoreline settlement. Daily larval settlement and the accumulation of barnacle recruits were both strongly correlated with local wind patterns within and among years. When prevailing winds were out of the south, larval settlement was enhanced on the northern side of the bay. whereas when winds were out of the north, larval settlement was enhanced on the southern side of the bay. These patterns were observed over 2 settlement seasons and led to daily as well as interannual spatial patterns in both larval settlement and the accumulation of barnacle recruits. The patterns of shoreline settlement appear to be caused by wind-induced changes in larval concentrations on different sides of the bay. Water column larval densities were strongly correlated with daily wind patterns. Larval densities were always highest on the down-wind side of the bay. Our data show that spatial and temporal patterns in the settlement of benthic invertebrates can be strongly linked to local weather conditions through the transport of larvae by wind-driven currents.
\end{abstract}

KEY WORDS: Dispersal Larval settlement - Recruitment Larval transport

\section{INTRODUCTION}

Considerable recent attention has been given to the role played by variation in recruitment on the structure of marine populations. Spatial and temporal variation in larval settlement and recruitment is widespread in benthic invertebrates (Bousfield 1955, De Wolf 1973, Sutherland 1974, Caffey 1985, Gaines \& Roughgarden 1985a, b) and fish (Hjort 1914, Sale 1977) and can strongly influence their abundance and distribution (Yoshioka 1982, Gaines \& Roughgarden 1985a, b). Variation in larval supply to marine populations can directly influence the distribution and abundance of marine organisms by dictating recruitment patterns (Sutherland 1974, Gaines \& Roughgarden 1985a, b, Gaines \& Bertness 1992) as well as influence popula-

•E-mail: mark_bertness@postoffice.brown.edu

Present addresses:

- Department of Ecology, Evolution and Marine Biology, University of Cahifornia, Santa Barbara. California 9.3106 , USA

-.Bigelow Laboratory, West Boothbay Harbor, Maine 04575 , USA tion and community interactions (for discussion see Sale 1977, Underwood \& Denley 1984, Roughgarden et al. 1988, Warner \& Hughes 1988, Menge 1991, Sanford et al. 1994). Elucidating the causes of variable recruitment in marine organisms is clearly crucial to understanding marine populations and communities.

Mechanisms responsible for generating variation in recruitment can operate on a range of spatial scales. At small spatial scales, in the size range of most sessile marine invertebrates (millimeters to tens of centimeters), larval settlement preferences and hydrodynamics are important. Larvae often settle preferentially with conspecifics (Crisp \& Meadows 1962, Pawlik et al. 1991) or respond to microfloral cues found in adult habitats (Strathmann et al. 1981, Yund et al. 1987) and are sensitive to a wide range of cues that can indicate favorable conditions for further development (see Meadows \& Campbell 1972 for review). Small-scale hydrodynamic forces, however, can also influence larval settlement rates (Butman 1987, Eckman 1990, Pawlik et al. 1991, Snelgrove et al. 1993). At slightly larger spatial scales of meters to tens of meters, factors that influence larval concentrations and the rate of 
larval delivery to potential habitats are critical. At this spatial scale, processes that dictate larval fluxes can play a major role. The flux of larvae arriving at a site can be set by surface waves, currents, internal waves, and tidal bores (Bousfield 1955, Hawkins \& Hartnoll 1982, Shanks 1983, 1986, Bertness et al. 1991, Pawlik et al. 1991, Pineda 1991, 1994, Gaines \& Bertness 1993). Finally, at very large, geographic spatial scales measured in tens to hundreds of kilometers, transport of larvae can also be important to generating spatial and temporal variation in settlement. For example, variation in the intensity of upwelling can influence shoreline larval settlement by affecting the spatial distribution of larvae in an onshore-offshore axis (Bailey 1981, Parrish et al, 1981, Roughgarden et al. 1987, Farrell et al. 1991, Botsford et al. 1994). Similarly, estuarine flushing can influence the settlement of invertebrates by dictating the retention and export of passively dispersed larvae from esluaries (Ketchumi 1954, Gaines \& Bertness 1992, 1993). Moreover, large-scale oceanographic currents also appear to play a major role in dictating the dispersal and biogeographic distribution of niarine organisms with pelagic development (Parrish et al. 1981, Cowen et al. 1993, Hare \& Cowen 1993). An understanding of the importance of settlement in regulating the abundance and distribution of marine populations will ultimately require integrating processes that affect recruitment across all of these spatial scales.

In this paper we examine the role of wind-driven larval transport in influencing spatial and temporal patterns in larval settlement at intermediate spatial scales that have been poorly studied - hundreds of meters to kilometers. Our work was stimulated by observations during our long-term study of spatial and temporal variation in the recruitment of the acorn barnacle Semibalanus balanoides (Bertness et al. 1991, Gaines \& Bertness 1992, 1993, Bertness \& Gaines 1993). We noticed a tendency for high settlement rates to correspond with strong onshore winds. Prior studies have also suggested a temporal correlation between settlement and wind direction (Boicourt 1982, Hawkins \& Hartnoll 1982, Kendall et al. 1982, 1985, but see Bennell 1981. Wethey 1985). These observations posed the hypothesis that if wind direction plays an important role in generating settlement variation, then nearby sites with similar shoreline orientations should have similar temporal dynamics of settlement. By contrast, sites with differing shoreline orientations may have settlement dynamics that are negatively correlated over time. To test this hypothesis we examined daily larval settlement, the annual accumulation of barnacle recruits, and water column larval concentrations of $S$. balanoides in relationship to wind conditions at sites on opposite sides of a small enclosed bay.
Acorn barnacles are ideal organisms to study linkages between larval dynamics and shoreline populations. Barnacle larvae are easily sampled and identified in plankton (Gaines \& Bertness 1993, Gaines \& Roughgarden 1985a, b), accurate estimates of shoreline settlement and recruitment are feasible (Connell 1985, Bertness et al. 1991), and the benthic dynamics of acorn barnacle populations have been extensively studied (e.g. Connell 1961, Wethey 1983, 1985).

\section{METHODS}

Semibalanus balanoides larval settlement and recruitment were monitored in 1991 and 1992 at 4 sites in Mt. Hope Bay, Rhode Island, USA. Mt. Hope Bay is a shallow (average depth $7 \mathrm{~m}, 20$ to $30 \mathrm{~m}$ maximum depth), sheltered, inland embayment of Narragansett Bay. Two monitoring sites (Common Fence Point and Beach Road) were located on the southern shore of the bay separated by $\sim 1 \mathrm{~km}$. The second 2 sites (Mt. Hope and Seal Cove) were located $\sim 1 \mathrm{~km}$ from each other on the northern shore of the bay, directly across the bay from the southern shore sites (Fig. 1). In January 1991, twenty $10 \times 10 \mathrm{~cm}$ permanent quadrats were haphazardly located on boulder surfaces at each site at intermediate $(+1.5 \mathrm{~m})$ tidal heights. Quadrats were marked with individually numbered stainless steel bolts. At each site quadrats were haphazardly assigned to 10 settlement and 10 recruitment quadrats and all adult barnacles and other sessile organisms were scraped from the substrate.

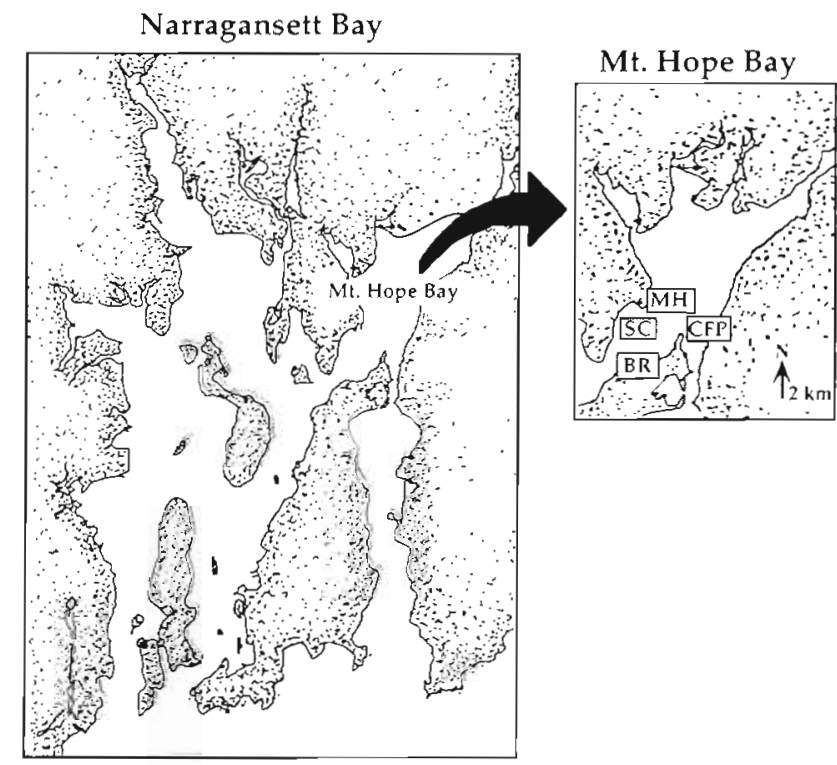

Fl.g. 1. Map showing the location of the Mt. Hope Bay study sites. $\mathrm{MH}=\mathrm{Mt}$. Hope, $\mathrm{SC}=\mathrm{Seal}$ Cove, $\mathrm{CFP}=\mathrm{Common}$ Fence Point BR = Beach Road 
We operationally define Semibalanus balanoides larval settlement as the daily arrival rate of larval settlers, and we define recruitment as the accumulation of metamorphosed $S$. balanoides juveniles (following Connell 1985). Daily larval settlement was monitored in the settlement quadrats at all sites in 1991 and 1992. In 1991, daily settlement was quantified for $23 \mathrm{~d}$ beginning on February 27. In 1992, daily settlement was quantified at all sites for $42 \mathrm{~d}$ beginning on February 17 In both years, most (>90\%) of the cumulative annual $S$. balanoides settlement occurred while we were quantifying settlement. $S$. balanoides larval settlement was quantified by counting attached barnacle cyprids at low tide in a centrally placed $5 \times 5 \mathrm{~cm}$ subquadrat within each numbered quadrat every day. After each daily count, all cyprids were removed with a soft brush and the surface was washed with seawater so that each day's counts included only cyprids that had settled during the previous 24 h period.

Wind direction measurements were taken daily at each site while monitoring settlement with a compass and hand-held anemometer (Omega HH-F10). These local measurements were found to be far superior predictors of local larval dynamics than measurements from nearby weather stations (authors' unpubl. data) due to the complex topography of the shoreline and bay.

Semibalanus balanoides recruitment was quantified at all sites by taking monthly (February to April) photographs of recruitment quadrats in 1991 and 1992. Recruitment quadrats were cleared of all barnacles and other sessile organisms in January of 1991 and 1992, 1 mo before $S$. balanoides settlement began. From monthly photographs, metamorphosed cyprids were counted to estimate recruitment success. In our daily visits to all field sites during the settlement season in both 1991 and 1992, no notable barnacle recruit mortality events were observed. At higher tidal heights, however, heavy recruit mortality was common. What recruit mortality we did observe at the intermediate tidal heights we studied was similar at all sites, suggesting that recruitment differences among sites were due to settlement rather than to recruit mortality differences among sites.

To examine the hypothesis that wind-driven barnacle settlement patterns were influenced by the distribution of larvae in the water column, we quantified water column larval densities adjacent to the northern and southern shore sites in 1992. Larval densities were sampled 50 to $75 \mathrm{~m}$ offshore with pumps constructed of $12 \mathrm{~V}$ bilge pumps modified to filter water through a $100 \mu \mathrm{m}$ mesh (Nytex). The pumps were deployed from a boat at depths of 1, 3, and $6 \mathrm{~m}$ (bottom) and powered withí a pur idbie generator Larval densities varied significantly with depth (mid water > bottom > shallow; repeated measures $\left.F_{2,22}=9.5, p<0.001\right)$, but the pat- tern of depth distribution did not vary among locations (depth by side of bay interaction, $F_{2,22}=2.45, \mathrm{p}>0.10$ ). As a result, we only analyzed the intermediate depth pump samples for comparison of the effects of wind driven transport. Larval densities were sampled every 5 to 7 d throughout the 1992 settlement season (FebruaryMarch, 8 total sampling dates). On each sampling day, 4 replicate 5 min pump samples were taken adjacent to the northern and southern sites and wind direction and speed were recorded. Pump samples were preserved in the field in formalin, and in the laboratory barnacle cyprids were counted under a dissecting microscope.

\section{RESULTS}

\section{Daily larval settlement}

Daily larval settlement of Semibalanus balanoides in Narragansett Bay was over an order of magnitude higher in 1992 than in 1991 (Fig. 2). Strong interannual variation in $S$. balanoides settlement density has previously been shown to be largely dictated by interannual variation in the likelihood of larval retention within the bay (Gaines \& Bertness 1992, 1993). Within years, however, there was also conspicuous variation in settlement. In both 1991 and 1992, day to day settlement varied by as much as an order of magnitude with no apparent periodicity (Fig 2), as has been shown in other systems (e.g. Shanks 1983, 1986, but see Wethey 1985). Moreover, the relative magnitude of daily settlement on northern versus southern sides of the bay varied markedly both within and between years (Fig. 2)

For each year, we examined daily variation in settlement with a repeated measurement ANOVA, with side of the bay (north vs south) as the between group factor. In 1991, settlement varied substantially between sides of the bay $\left(F_{1,18}=77.5, \mathrm{p}<0.0001\right)$ and over time $\left(F_{19,304}=32.5, \mathrm{p}<0.0001\right)$ with a strong $\left(F_{19,304}=20.2\right.$, $\mathrm{p}<0.0001$ ) side of bay $\times$ time interaction. Mean daily settlement in 1991 was over twice as high on southern shores $\left(18.7 \pm 1.3\right.$ settlers $\left.100 \mathrm{~cm}^{-2}\right)$ than on northern shores $\left(7.7 \pm 0.9\right.$ settlers $\left.100 \mathrm{~cm}^{-2}\right)$. In 1992 , settlement rates varied significantly over time $\left(F_{25.400}=18.6, \mathrm{p}<\right.$ 0.0001 ), and there was a significant time $x$ side of bay interaction $\left(F_{25,400}=9.7, p<0.0001\right)$. In 1992, however, mean daily settlement was not significantly different among sides of the bay $\left(F_{1,24}=2.5, \mathrm{p}<0.13\right)$, although settlement was over $40 \%$ higher $(707.6 \pm 45.6$ settlers $\left.100 \mathrm{~cm}^{-2}\right)$ on southern than on northern (515.9 \pm 20.7 settlers $100 \mathrm{~cm}^{-2}$ ) shores. Thus, in 1991, daily $S$. balanoides larval settlement was higher on southern than on northern shores, whereas in 1992 northern shores received heavier settlement than southern shores (Fig. 2). 


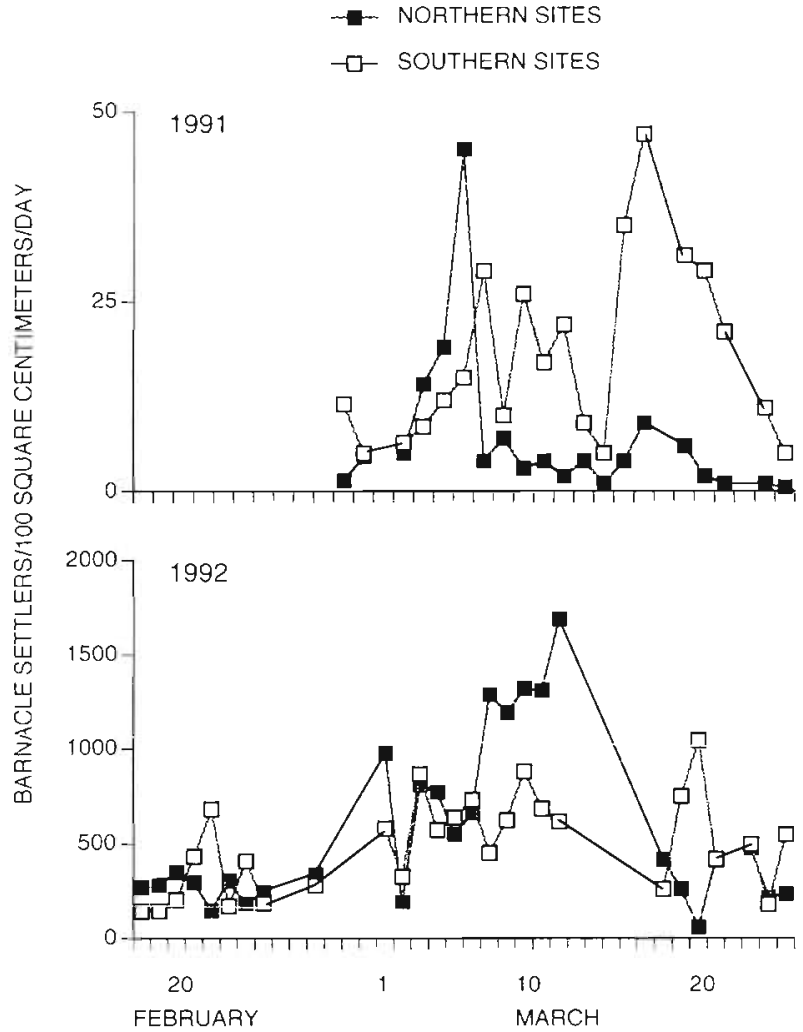

Fig. 2. Semibalānus balanoides. Mean daily accumulation of settlers (attached cyprids) to cleared (daily) quadrats at intermediate $(+1.5 \mathrm{~m})$ tidal heights at northern and southern sites in Mt. Hope Bay in 1991 and 1992. Each point represents the mean of 20 counts (10 per site for each side of the bay) Standard errors are not shown since they are always smaller than the symbols

\section{Annual recruitment}

Semibalanus balanoides recruitment matched interannual variation in settlement densities as well as interannual differences in settlement rates between southern and northern sides of the bay (Fig. 3). We analyzed the recruitment data (final densities in April) with a 2-way year (1991 and 1992) x side of bay (northern vs southern) ANOVA with sites nested within side of the bay. Recruitment rates did not vary among years $\left(F_{1,1}=8.69, p>0.20\right)$, sides of the bay $\left(F_{1,1}=0.174, p>\right.$ $0.7)$, or sites within sides of the bay $\left(F_{2,1}=0.95, p>0.5\right)$ largely because of a highly significant year $\times$ side of the bay interaction $\left(F_{1,74}=45.7, \mathrm{p}<0.0001\right)$. S. balanoides recruit densities were 6 times higher in 1992 than in 1991 (Fig. 3), but the ranking of sites and side of the bay changed substantially between years, reflecting the large differences in settlement rates. In 1991, when settlers were more common on southern shores of the bay, recruits were nearly 4 times more

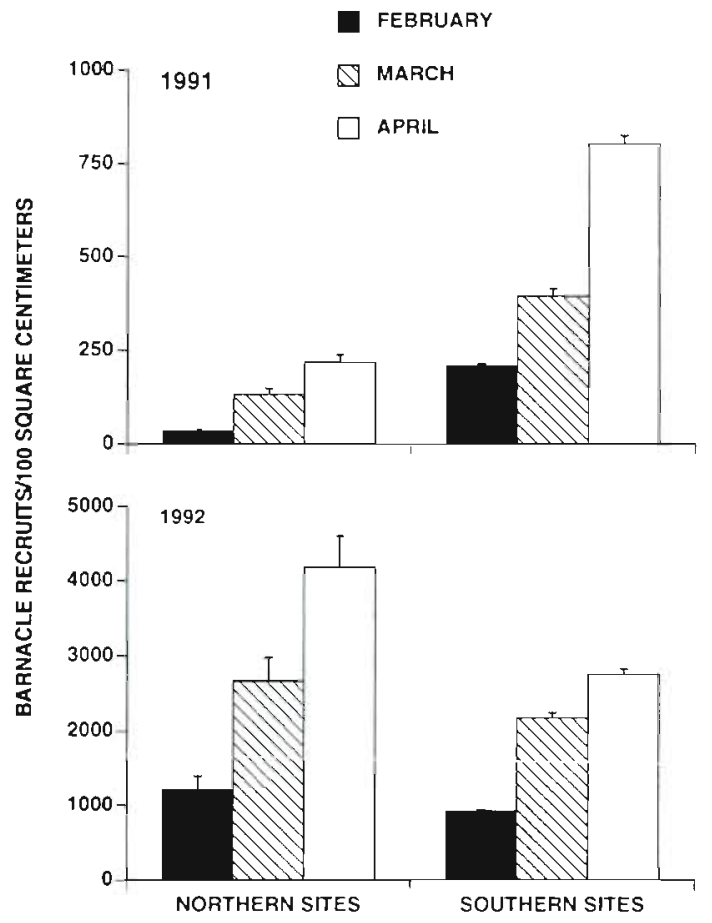

Fig. 3. Semibalanus balanoides. Mean $( \pm \mathrm{SE})$ monthly accumulation of metamorphosed recruits to intermediate tida height $(+1.5 \mathrm{~m})$ quadrats in 1991 and 1992. Each bar represents the mean of 20 quadrats (10 per site for each side of the bay)

common at southern than at northern sites. Conversely, in 1992 when settlers were more common at northern sites, recruits were nearly twice as abundant at northern sites as at southern sites (Fig. 3).

The pronounced interannual variation in settlement and recruitment on northern and southern sides of $\mathrm{Mt}$. Hope Bay was correlated with interannual variation in prevailing wind directions in 1991 and 1992 during larval settlement (Fig. 4). In 1991, 65\% of the daily wind readings were out of the north $\left(300\right.$ to $\left.60^{\circ}\right)$. In contrast, in $1992,61 \%$ of the daily wind readings were out of the south $\left(120\right.$ to $\left.240^{\circ}\right)$. Together with the annual spatial patterns in settlement and recruitment (Figs. $2 \& 3$ ), these data suggest a relationship between wind direction and Semibalanus balanoides settlement.

\section{Correlations between daily settlement and wind direction}

The correspondence between average annual wind patterns and settlement differences among shores suggests a possible link. To explore the connection further, we also examined the correspondence between daily settlement and wind directions. For each day we calculated the average settlement rate for the entire bay and 

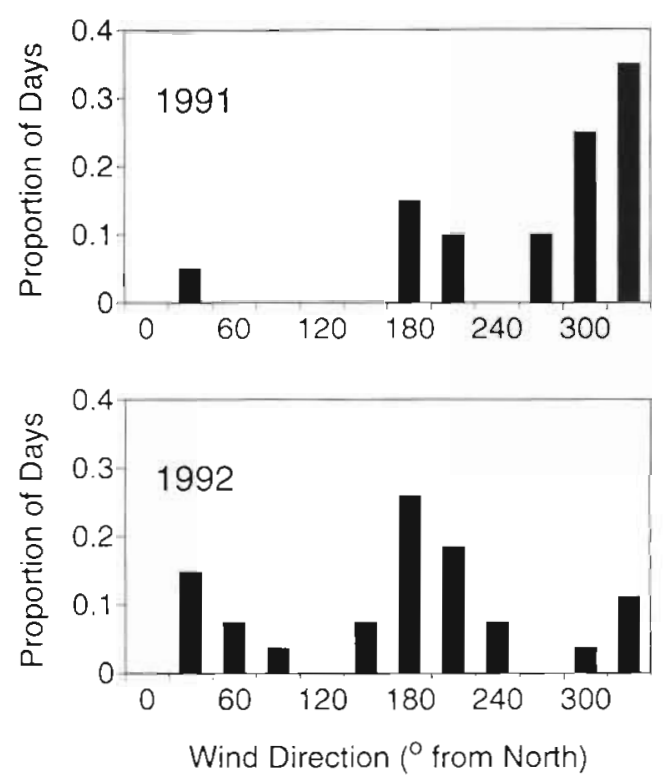

Fig. 4. Distributions of wind directions in 1991 and 1992 during the period of daily settlement of Semibalanus balanoides

then expressed settlement rates to individual quadrats as deviations from these daily means. Expressing settlement rates as deviations from the daily mean eliminated the large day to day variation in overall settlement rates that might obscure the spatial pattern of settlement within the bay. We compared the pattern of settlement deviations for quadrats from different sides of the bay with the daily wind directions. If northerly winds increase settlement at southern sites relative to northern sites, then when the winds are from the north we would expect positive settlement deviations (i.e. settlement rates $>$ the bay-wide average for a day) at southern sites and negative deviations at northern sites. Similarly, if southerly winds increase settlement at northern sites relative to southern sites, then when the winds are from the south we would expect positive deviations at northern sites and negative deviations at southern sites.

To graphically present these data, we have plotted deviations from daily settlement averages versus wind direction in polar plots. The angle within the circle is the angle of the wind on a given day, and the radius from the center of the plot corresponds to the settlement rate deviation. Each figure has 2 regions. The central ring (shaded) corresponds to negative settlement deviations (i.e. < daily mean). The outer ring corresponds to positive deviations (i.e. > daily mean). In 1991 (Fig. 5), winds were predominately out of the north/northwest, and all days with these northerly winds had greater settlement on southern than on northern shores (i.e. all open circles in the top half of Fig. 5 are in the outer ring). Northern shores only had

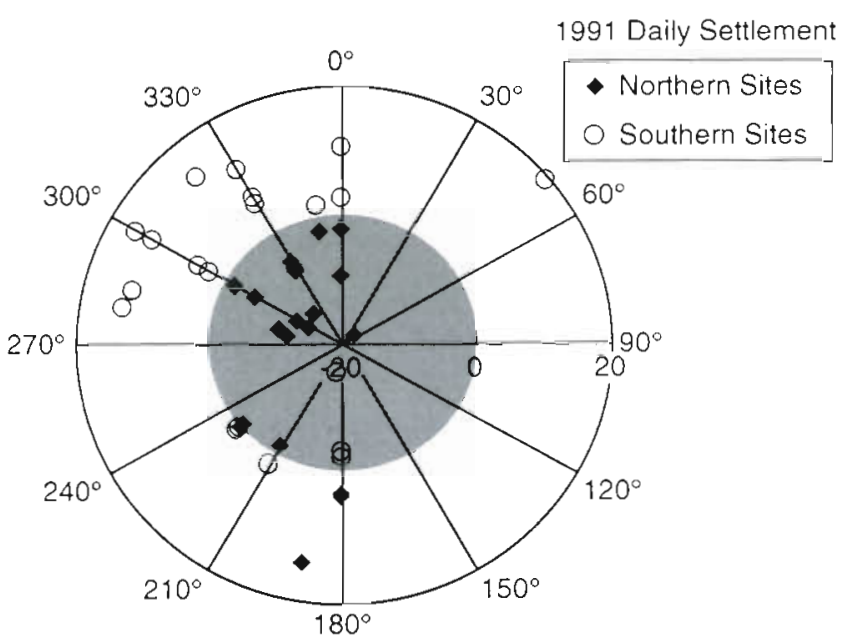

Fig. 5. Semibalanus balanoides. Daily settlement in 1991 at northern and southern shoreline sites as a function of wind direction. Each point represents the deviation of mean daily settlement on northern and southern shores from total pooled (northern and southern shores) mean daily settlement. See text for discussion and statistics

settlement rates greater than the daily mean on days with southerly winds (Fig. 5). A similar pattern was seen in 1992 (Fig. 6). On days with northerly winds, $80 \%$ of the southern shore sites had higher settlement than northern shore sites $89 \%$ of the time. By contrast, on days with southerly winds, northern sites had higher settlement than southern sites $87 \%$ of the time (Fig. 6). There were no consistent settlement patterns on the few days when winds came predominantly from the east. Indeed, on these days, settlement rates at

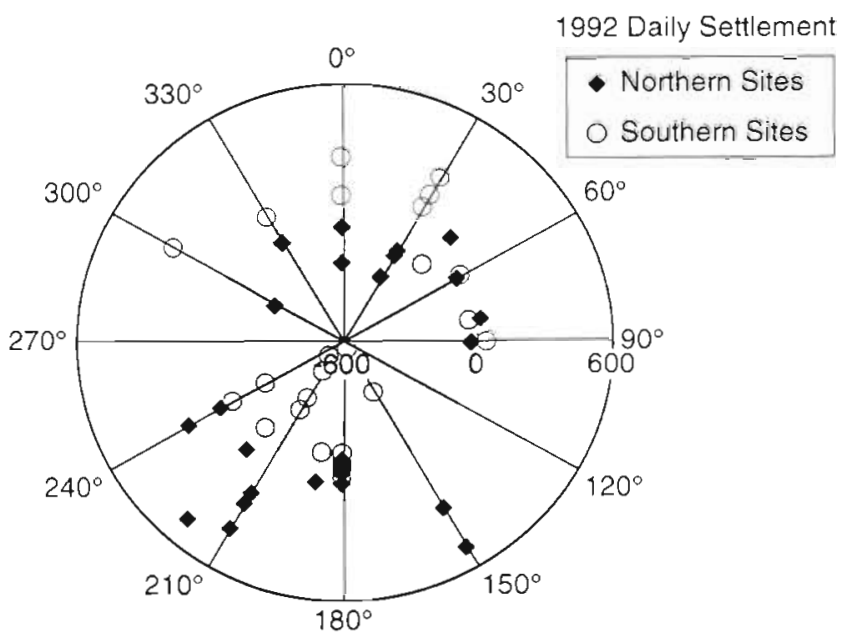

Fig. 6. Semibalanus balanoides. Daily settlement in 1992 at norinern and southern shorelune sites as a function of daily variation in wind direction. As in Fig. 4 each point represents the deviation in mean settlement from pooled daily mean settIement on northern and southern sites 


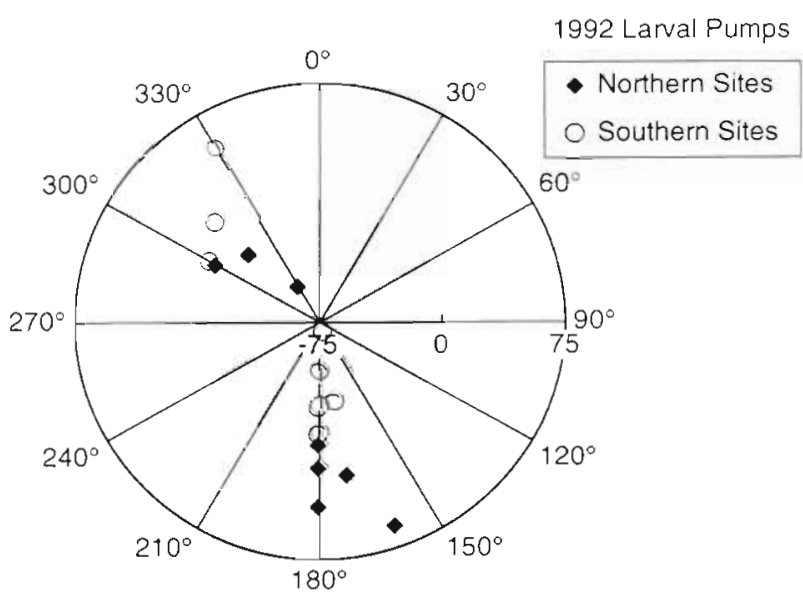

Fig. 7 Semibalanus balanoides. Daily water column larval densities in 1992 as a function of wind directions. Each point represents the deviation of mean larval concentrations adjacent to southern and northern shores from total ponled (southern and northern shores). See text for discussion and statistics

southern and northern sites were nearly identical. Including both years, the correspondence between wind direction (northerly vs southerly) and greater settlement on northern versus southern shores was highly significant $\left(\chi^{2}=34.83, p<0.00001\right)$.

\section{Correlations between water column larval concentrations and wind directions}

Water column larval densities adjacent to northern and southern shores are presented in Fig. 7 as deviations from average larval densities on each sampling date. Although we only collected larvae on 8 sampling dates, larval concentrations on the northern and southern sides of the bay showed a perfect correlation with wind direction. On the 3 sampling dates when winds were out of the north more barnacle larvae were found adjacent to southern than to northern shores (Fig. 7). Conversely, on the 5 sampling days when winds were out of the south, larval concentrations were higher adjacent to northern than southern shores (Fig. 7). These results suggest that the correlation between onshore winds and larval settlement is driven by windinduced changes in the distribution of larvae on different sides of the bay.

\section{DISCUSSION}

Our results support growing evidence that larval transport can play a critical role in dictating larval settlement and recruitment patterns in marine organisms with pelagic larvae. Moreover, in light of our previous work with Semibalanus balanoides recruitment, this work also suggests that by integrating studies of recruitment variation across spatial scales, a predictive understanding of local recruitment variation is possible

\section{Linkages between oceanographic conditions, larval transport, and settlement}

Our results show that wind-driven onshore winds can transport barnacle larvae shoreward and increase settlement. Previously we have shown that interannual variation in bay flushing can strongly affect annual larval supplies (Gaines \& Bertness 1992). Within years, however, we have shown here that spatial and temporal variation in settlement within bays may be strongly correlated with wind direction, with onshore winds stimuiating seilienent. Our resilts suggest that annual variation in prevailing winds can leave annual signatures on both settlement and recruitment patterns (sensu Connell 1985), In 1991, in Mt. Hope Bay winds were predominatcly from the north and led to heavier settlement and recruitment on southern than on northern shores. Conversely, in 1992, when winds were predominately from the south, both settlement and recruitment were heavier on northern shores. These patterns could be influenced by wave-exposed shorelines receiving higher flows and larval fluxes than less exposed shorelines (Bertness et al. 1991, Gaines \& Bertness 1993) or by the preferential settlement of larvae in turbulent water (see Meadows \& Cambell 1972 for review). Water column larval concentrations, however, were also strongly correlated with wind patterns, suggesting that larval transport was largely responsible for the results.

These findings contribute to growing evidence that larval transport influences the settlement and recruitment of marine organisms with pelagic larvae. On the Isle of Man, UK, Hawkins \& Hartnoll (1982) also found that high settlement of Semibalanus balanoides was correlated with onshore winds (see also Boicourt 1982, Kendall et al. 1982, 1985). Others, however, have found no correlations between daily larval settlement and wind direction (Bennell 1981, Wethey 1985). Shanks (1983, 1986) found no correlation between wind direction and the distribution of crab and barnacle larvae, but his studies suggested that benthic larvae may be transported onshore in slicks by tidally forced internal waves. Recent studies by Pineda (1991. 1994) have further suggested that tidal bores may commonly transport larvae to shore in coastal environments. Our data (Fig. 2), from a shallow estuarine habitat, revealed no temporal settlement patterns associated with tidal periodicity. How much our results are 
an artifact of Mt. Hope Bay being a very shallow embayment or are peculiar to Semibalanus balanoides cyprids is not known. On much larger spatial scales, larval transport by ocean circulation patterns (Bailey 1981, Parrish et al. 1981, Cowen et al. 1993), upwelling systems (Roughgarden et al. 1987), and estuary flushing (Ketchum 1954, Gaines \& Bertness 1992) appear to be common.

\section{Integrating forces that influence settlement across spatial scales}

Understanding the processes that generate variation in the settlement and recruitment of marine species with planktonic dispersal is a difficult problem. Local larval supplies are clearly dictated by processes operating on a wide range of spatial scales and are sensitive to both larval concentrations and delivery rates. Given this complexity, is local variation in settlement predictable? Our long-term studies of Semibalanus balanoides recruitment in Narragansett Bay suggest that it is.

On large, bay-wide geographic spatial scales, we have found that interannual variation in Semibalanus balanoides settlement and recruitment is largely a function of interannual variation in estuary flushing (Gaines \& Bertness 1992, 1993). In years of heavy rainfall and high flushing, $S$. balanoides larvae are flushed out of the bay and recruitment within the bay is low. In contrast, in years of low rainfall, bay flushing is slow, larvae are retained in the bay, and settlement and recruitment in the bay are high. Over a $10 \mathrm{yr}$ period, variation in bay flushing accounted for over $80 \%$ of interannual variation in $S$. balanoides recruitment.

Within years, we have further shown that local oceanographic features operating at scales of tens of meters to kilometers predictably influence settlement. Since increased flow speeds increase the flux of larvae over potential benthic habitats /Gaines \& Bertness 1993), we have shown that shoreline features that enhance flow speeds such as constrictions or islands that occlude flows, predictably increase Semibalanus balanoides settlement and recruitment (Sanford et al. 1994). Moreover, in this paper we have demonstrated that in any given year prevailing wind patterns can transport larvae and predictably influence spatial and temporal patterns of recruitment within the bay. Thus, while annual flushing patterns dictate annual larval concentrations, in a given year, local oceanographic conditions lead to spatially predictable variation in recruitment.

At eveil shalier spatial scales we have found that surface features which influence settlement at scales measured in millimeters to tens of centimeters are tightly linked to larger scale variation in larval supplies. Whereas barnacles settle adjacent to conspecifics, at lower tidal heights, on wave-exposed surfaces, and in crevices (for review see Meadows \& Cambell 1972), these small-scale patterns in larval settlement are only evident in recruitment when larval supplies are relatively low (Bertness et al. 1991) With high larval supplies, saturation of settlement sites obscures small-scale patterns in settlement and recruitment. Consequently, in years of low larval retention, and in habitats exposed to low flows, smallscale spatial patterns in recruitment are predictably distinct. Conversely, in years of high larval retention and in habitats exposed to high larval fluxes, habitat saturation by settlers hides underlying small-scale spatial variation in settlement.

Together our studies suggest that local variation in the recruitment of marine organisms with pelagic dispersal can only be understood by simultaneously considering the forces that influence settlement across different spatial scales.

Acknowledgements. We thank E. Sanford, S. Hacker and K. Kim for field and laboratory assistance and S. Morgan, S. Hacker, J. Witman and 3 anonymous reviewers for comments. Our work was supported by grants from the Andrew Mellon Foundation and the Biological Oceanography Program of the National Science Foundation.

\section{LITERATURE CITED}

Bailey KM (1981) Larval transport and recruitment of Pacific hake Merluccius productus. Mar Ecol Prog Ser 6:1-9

Bennell SJ (1981 Some observations on the littoral barnacle populations of North Wales. Mar Environ Res 5:227-240

Bertness MD, Gaines SD (1993) Larval dispersal and local adaptation in acorn barnacles. Evolution 47:316-320

Bertness MD, Gaines SD, Stephens EG, Yund PO (1991) Components of recruitment in populations of the acorn barnacle Semibalanus balanoides (Linnaeus). J Exp Mar Biol Ecol 156:199-215

Boicourt SJ (1982) Estuarine larval retention mechanisms on two scales. In: Kennedy VS (ed) Estuarine comparisons. Academic Press, New York, p 445-457

Botsford LW, Moloney CL, Hastings A, Largier JL, Powell TM, Higgins K, Quinn JF (1994) The influence of spatially and temporally varying oceanographic conditions on meroplanktonic metapopulations. Deep Sea Res 41:107-145

Bousfield EL (1955) Ecological control of the occurrence of barnacles in the Miramichi estuary. Nat Mus Can Bull $137: 1-69$

Butman CA (1987) Larval settlement of soft-sediment invertebrates: the spatial scales of pattern explained by active habitat selection and the emerging role of hydrodynamic processes. Oceanogr Mar Biol A Rev 25:113-165

Caffey HM (1985) Spatial and temporal variation in settlement and recruitment of intertidal barnacles. Ecol Monogr 5j.313-332

Connell JH (1961) Effects of competition, predation by Thais lapillus and other factors on natural populations of the barnacle Balanus balanoides. Ecol Monogr 31:61-104 
Connell JH (1985) The consequences of variation in initial settlement vs post settlement mortality in rocky intertidal communities. J Exp Mar Biol Ecol 93:11-45

Cowen RK, Hare JA. Fahay MP (1993) Beyond hydrography: can physical processes explain larval fish assemblages within the Middle Atlantic Bight? Bull Mar Sci 53:567-587

Crisp DJ, Meadows PS (1962) The chemical basis of gregariousness in cirripeds. Proc R Soc London Ser B 156:500-520

De Wolf P (1973) Ecological observations on the mechanisms of dispersal of barnacle larvae during planktonic life and settling. Neth J Sea Res 6:1-129

Eckman JE (1990) A model of passive settlement by planktonic larvae onto bottoms of differing roughness. Limnol Oceanogr 35:887-901

Farrell T, Bracher D, Roughgarden J (1991) Cross-shelf transport causes recruitment to intertidal populations in central California. Limnol Oceanogr 36:279-288

Gaines SD, Bertness MD (1992) Dispersal and the loss of juveniles in sessile marine species. Nature 360:579-580

Gaine SD, Bertness MD (1993) Measurng juvenile dispersal: why field ecologists must learn to integrate. Ecology 74 : $2430-2435$

Gaines SD, Roughgarden J (1983a) Fish in ofishore kelp forests affect recruitment to intertidal barnacle populations. Science 235:479-481

Gaines SD, Roughgarden J (1985b) Larval settlement rate: a leading determinant of structure in an ecological community of the rocky intertıdal zone. Froc Nai Acad Sci USA 82:3707-3711

Hare JA, Cowen R.K (1993) Ecological and evolutionary implications of the larval transport and reproductive strategy of bluefish Pomatomus saltatrix. Mar Ecol Prog Ser 98:1-16

Hawkins SJ, Hartnoll RG (1982) Settlement patterns of Semibalanus balanoides (L.) in the Isle of Man (1977-1981). J Exp Mar Biol Ecol 62:271-283

Hjort J (1914) Fluctuations in the great fisheries of northern Europe viewed in the light of biological research. Rapp PV Réun Cons Perm Int Explor Mer 20:1-228

Kendall MA, Bowman RS, Williamson P, Lewis JR (1982) Settlement patterns, density and stability in the barnacle $B a l$ anus balanoides. Neth J Sea Res 16:119-126

Kendall MA, Bowman RS, Williamson P, Lewis JR (1985) Annual variation in the recruitment of Semibalanus balanoides on the North Yorkshire coast 1969-1981 J Mar Biol Ass UK 65:1009-1030

Ketchum BH (1954) Relation between circulation and planktonic populations in estuaries. Ecology 35:191-200

Meadows PS, Cambell JI (1.972) Habitat selection by aquatic invertebrates. Adv Mar Biol 10:271-382

Menge BA (1991) Relatıve importance of recruitment and other causes of variation in rocky intertidal community structure. J Exp Mar Biol Ecol 148:89-100

Parrish RH, Nelson CS, Bakun A (1981) Transport mechanisms and reproductive success of fishers in the California Current. Biol. Oceanogr 1:175-203

Pawlik JR, Butman CA, Starczak VR (1991) Hydrodynamic facilitation of gregarious settlement of a reef-building tube worm. Science 251:421-424

This article was presented by R. H. Karlson (Senior Editorial Advisor), Newark, Delaware, USA
Pineda $J$ (1991) Predictable upwelling and shoreward trans port of planktonic larvae by internal tidal bores. Science 253:548-551

Pineda J (1994) Internal tidal bores in the nearshore: warm water fronts, seaward gravity currents and the onshore transport of larvae. J Mar Res 52:427-458

Roughgarden J, Gaines SD, Pacala SW (1987) Supply side ecology: the role of physical transport processes. In Gee $\mathrm{JH}$, Giller PS (eds) Organization of communities - past and present. Blackwell Scientific, London, p $491-581$

Roughgarden J, Gaines SD, Possingham H (1988) Recruitment dynamics in complex life cycles. Science 241 $1460-1466$

Sale PF (1977) Maintenance of high diversity in coral reef fish communities. Am Nat 111:337-359

Sanford G, Bermudez D, Bertness MD, Gaines SD (1994) Flow food supply and acorn barnacle population dynamics. Mar Ecol Prog Ser 104:49-62

Shanks AL (1983) Surface slicks associated with tidally forced internal waves may transport pelagic larvae of benthic invertebrates and fish shoreward. Mar Ecol Prog Ser 24 $280-295$

Shanks AL (1986) Tidal periodicity in the daily settlement of intertidal barnacle larvae and an hypothesized mecha. nism for the cross-shelf transport of cyprids. Biol Bull 170:429-440

Snelgrove RVR, Butman CA, Grassle JP (1993) Hydrodynamic enhancement of larval settlement in the bivalve Mulinia lateralis (Say) and the polychaete Capitella sp. I in microdepositional environments. J Exp Mar Biol Ecol 168: $71-109$

Strathmann RR, Branscomb ES, Vedder K (1981) Fatal errors in set as a cost of dispersal and the influence of intertidal flora on set of barmacles. Oecologia 48:13-18

Sutherland JP (1974) Multiple stability points in natural communities. Am Nat 108:859-873

Underwood AJ, Denley E (1984) Paradigms, explanations, and generalizations in models for the structure of intertidal communities on rocky shores. In: Strong DR, Simberloff $\mathrm{D}$, Ablele L, Thistle A (eds) Ecological communities. Princeton University Press, Princeton, p 151-180

Warner RR, Hughes TP (1988) The population dynamics of reef fish. Proc 6th Int Symp Coral Reefs 1:149-155

Wethey DS (1983) Geographic limits and local zonation: the barnacles Semubalanus and Chthamalus in New England Biol Bull 165:330-341

Wethey DS (1985) Local and regional variations in settlement and survival in the littoral barnacle Semibalanus balanoides: patterns and consequences. In: Seed R, Moore PG (eds) The ecology of rocky coasts. Hodder and Stoughton, London, p 194-202

Yoshioka PM (1982) Role of planktonic and benthic factors in the population dynamics of the bryozoan Membranipora membranacea. Ecology 63:457-468

Yund PO, Cunningham CW, Buss LW (1987) Recruitment and postrecruitment interactions in a colonial hydroid. Ecology $68: 971-982$

Manuscript first received: November 3, 1995 Revised version accepted: February 20, 1996 